\title{
審査腹腔鏡が診断の一助となった後腹膜妊娠
}

掛川市・袋井市企業団立 中東遠総合医療センター 産婦人科

田中 晶、林 立弘、小田木秋人、小池 洋、村上裕介

\section{A case of retroperitoneal ectopic pregnancy diagnosed using exploratory laparoscopy}

\author{
Aki Tanaka, Tatsuhiro Hayashi, Akito Oagi, Hiroshi Koike, Yusuke Murakami \\ Department of Obstertics and Gynecology, Chutoen General Medical Center
}

\begin{abstract}
Retroperitoneal ectopic pregnancy (REP) is rare. Laparoscopy is useful to diagnose a typical ectopic pregnancy and for removal of trophoblastic tissue. We report a case of REP diagnosed using exploratory laparoscopy. A 30-year-old, gravida 3 para 0 was admitted to our hospital with a history of 5 weeks' amenorrhea and suspected an ectopic pregnancy because of the empty uterus. Her obstetric history included a spontaneous abortion 8 years prior and laparoscopic left salpingectomy for a left tubal pregnancy, 6 years prior to presentation. She was completely asymptomatic and hemodynamically stable. Her serum human chorionic gonadotropin (hCG) level on admission was $3268 \mathrm{mIU} / \mathrm{mL}$, which subsequently increased to $5654 \mathrm{mIU} / \mathrm{mL}, 2$ days later. Transvaginal ultrasonography revealed a slightly edematous right fallopian tube. Exploratory laparoscopy was performed for suspected right tubal pregnancy; however, we did not detect any evidence of ectopic pregnancy. The serum hCG levels continued to increase postoperatively. Contrast-enhanced computed tomography performed to screen for trophoblastic disease revealed a ring-enhancing cystic mass in the left paraaortic region. Transabdominal ultrasonography revealed a gestational sac-like mass without a yolk sac and fetal heartbeat. We performed laparotomy and identified the gestational sac in the retroperitoneal space and removed all trophoblastic tissue. Diagnosis of REP is challenging on routine ultrasonography on routine evaluation. Exploratory laparoscopy is useful in the diagnosis of REP together with other imaging modalities to exclude other conditions.
\end{abstract}

Key words: Ectopic Pregnancy, Retroperioneal Space, laparoscopy

\section{【緒言】}

後腹膜妊娠は非常に稀な異所性妊娠で、異所性 妊娠に占める割合は $0.2 \%$ 以下である ${ }^{1)}$ 。希少性ゆ えに産婦人科医も通常、異所性妊娠の局在として 後腹膜妊娠を認識していない。異所性妊娠は母体 死亡の $2.7 〜 3.4 \%$ 占める婦人科救急疾患の一つ であり ${ }^{2,3)}$ 、早期診断、治療が必要である。不正出 血、腹腔内出血によるショック症状、下腹部痛と いった異所性妊娠の典型的な症状を呈する場合は もちろんであるが、近年は無症状でも経胵超音波 検査の普及により骨盤内腫瘤や腹水を捉えられる ため、異所性妊娠を早期に診断することが可能と なった。しかし後腹膜妊娠は腹腔内出血がないた
め典型的な症状がないばかりか、妊娠部位が経腟 超音波検査では描出できない範囲であることも多 く早期診断が難しい。後腹膜妊娠の診断の遅れは 後腹膜血管への絨毛浸潤や手術による大血管損傷 など、重大な合併症を引き起こす可能性もある。 しかしながら後腹膜妊娠の診断、治療についての 確実な方針はない。

今回、異所性妊娠を疑って審査腹腔鏡を行い、 腹腔内妊娠はないことを確認し、その審査腹腔鏡 所見が一助となり、その後の画像診断と合わせて 後腹膜妊娠と診断した症例を経験した。術前に䋐 毛組織と後腹膜血管との解剖学的な位置を検討 し、手術で大血管を損傷することなく絨毛組織を 完全摘出することができた。なお、本症例の報告 
について患者からの文書での同意を得ている。

\section{【症例】}

患者は30歳、3 妊 0 産、22歳の時に自然流産、 24歳の時に左卵管妊娠に対して腹腔鏡下左卵管切 除術の既往がある。最終月経より妊娠 5 週 4 日妊 娠反応が陽性となり近医を受診したが、子宮内に 胎囊を確認することができず、異所性妊娠の疑い で当科へ紹介された。血中 hCG $3268 \mathrm{mIU} / \mathrm{ml}$ 、 経腟超音波検查で右卵管の腫大を認めたが、腹水 の貯留はなかった。自覚症状はなくバイタルサイ ンも安定していたが、右卵管妊娠の疑いで入院の 上、経過観察を行った。入院 2 日目、全身状態や 超音波検查での右卵管や腹水の所見に著変はなか ったが、hCG值は5654 $\mathrm{mIU} / \mathrm{ml}$ へ上昇したため、 右卵管妊娠を疑い審査腹腔鏡を行った。腹腔内に 腹水を認めず、右卵管に有意な腫大を認めなかっ た。左卵巣に黄体と思われる $1 \mathrm{~cm}$ 大の囊胞を認 めたほか、大網など上腹部まで腹腔鏡で確認した が腹膜に妊娠所見はなかった（図 1 )。左卵管切 除術の既往がある未産婦であるため、右卵管は温

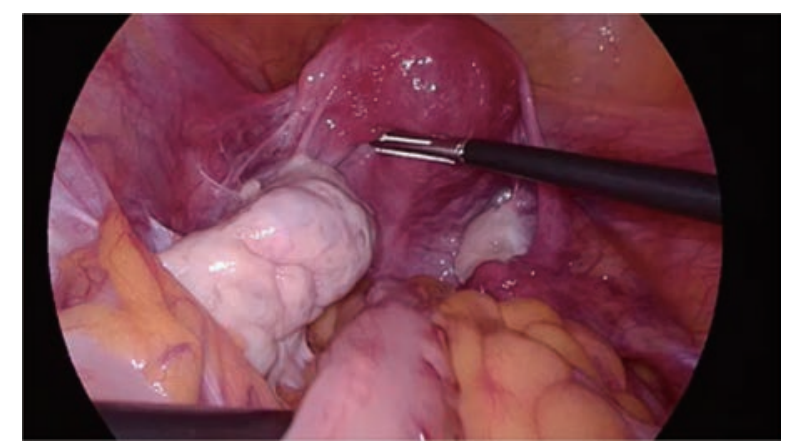

a

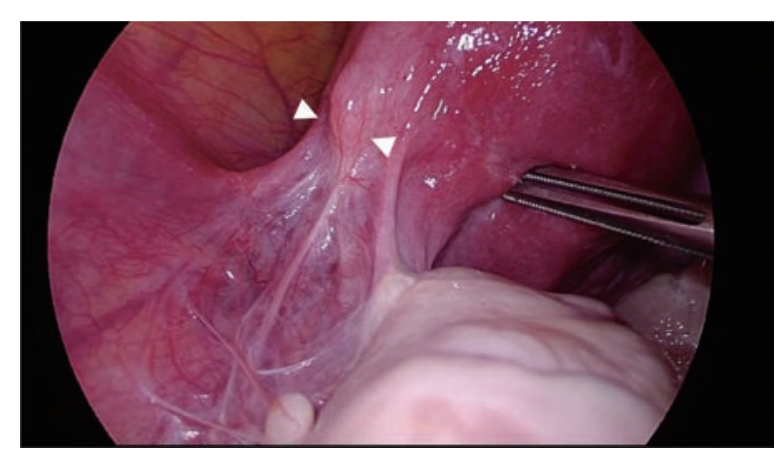

b
存した。子宮内容除去術を追加したが、子宮内容 は脱落膜変化を伴った子宮内膜組織であった。患 者および家族には審查腹腔鏡では右卵管妊娠と確 定することができず、右卵管を摘出すると今後自 然妊娠ができなくなることから摘出は行わなかっ たこと、腹腔鏡で確認できた範囲内に妊娠部位は 認められなかったこと、妊娠ホルモン（hCG）が 出ている限りは引き続き異所性妊娠として慎重な 経過観察が必要であることを伝えた。

審查腹腔鏡後もhCG值は上昇したため、異所性 hCG産生腫瘍も念頭に置き造影CT検査を行った ところ、下行大動脈左側、下腸間膜動脈分岐部上 り末梢側の後腹膜腔の、低位傍大動脈リンパ節領 域に、周囲がリング状に造影される $16 \mathrm{~mm}$ の震胞 性腫瘤を認めた。造影MRI検査でも同様の所見で あった。経腹超音波検査でも同部位に襄胞を確認 することができたが、卵黄囊や胎児心拍は明らか でなかった（図 2 )。自覚症状はなかったが、入

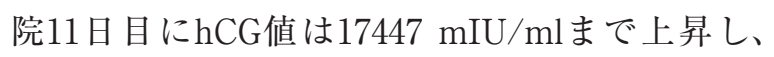
経腹超音波検査でも囊胞径が 4 日間で $4 \mathrm{~mm}$ 程度 増大したため、後腹膜妊娠を疑い、開腹手術を行

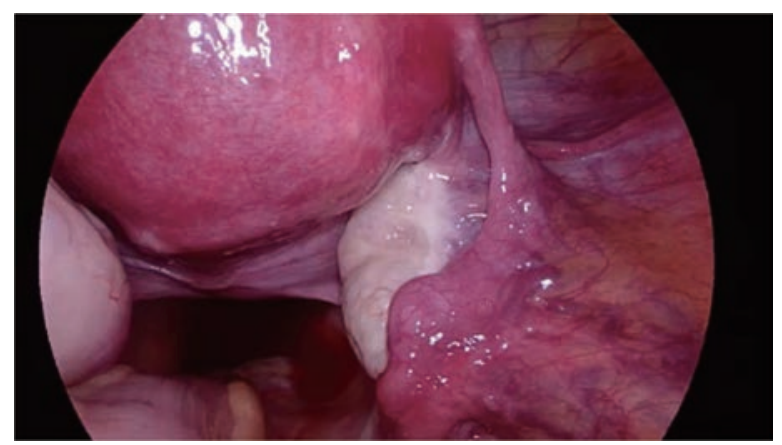

c

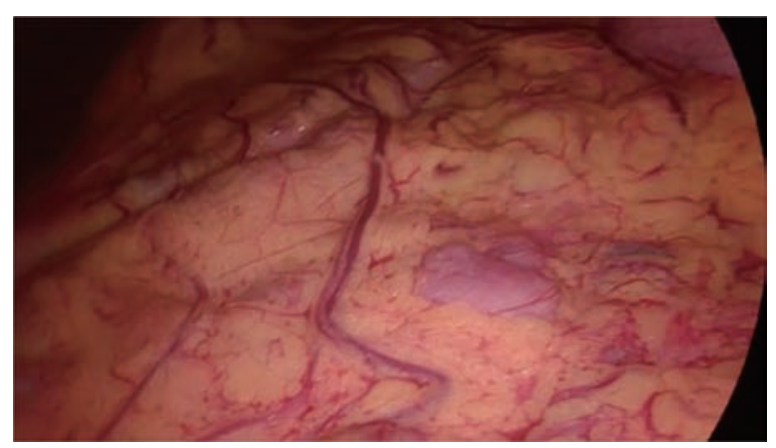

d

図 1 審査腹腔鏡所見

a. 左卵管は摘出後で、左卵巣には黄体囊胞を認めた。

b. 左卵管の切除断端 $(\nabla)$ は強固な癒着はなかったが腹膜に覆われ、周囲腹膜と連続していた。

c. 右付属器 : 右卵管には有意な所見は認めず、右卵巣は正常であった。

d. 腹腔内には明らかな妊娠部位を確認することはできなかった。 
った。あらかじめ左卵巣妊娠を否定する目的で左 卵巣囊胞を摘出し、迅速病理検査を行い黄体囊胞 であることを確認した。腹部大動脈左側は $2 \mathrm{~cm}$ 程度膨隆しており、腹膜表面は平滑であった（図 3 a)。術中超音波検查で腫瘤を確認しながら、腹 部大動脈に沿って腹膜を切開し後腹膜腔を展開し たところ、易出血性の腫瘤を確認した。下腸間膜 動脈、左卵巣動静脈および尿管を同定しながら、 下行大動脈左側と腰椎および腸腰筋から腫瘤を摘 出した（図 $3 b)$ 。迅速病理検査で腫瘤内に絨毛 が含まれることを確認した。腫瘤は完全摘出でき、 止血も可能であった。手術時間は 3 時間21分、術 中出血は $145 \mathrm{ml}$ であた。術後病理診断で後腹膜 腫瘤に絨毛を認め、後腹膜妊娠と診断をした（図 4)。hCG值は術後順調に低下し、開腹術後43日 目で陰性化した。

\section{【考察】}

本症例では審査腹腔鏡により卵管妊娠や腹腔内 妊娠を除外できたことが、後腹膜妊娠という極め て稀な異所性妊娠を診断する一助となった。審査

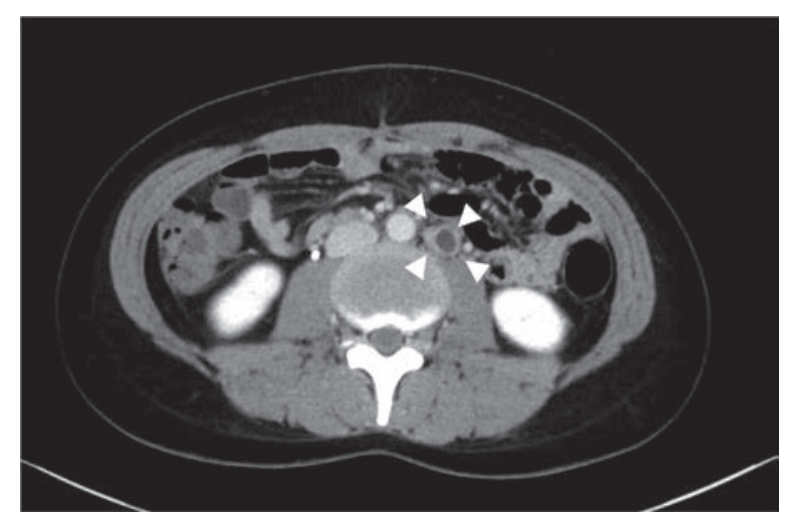

a

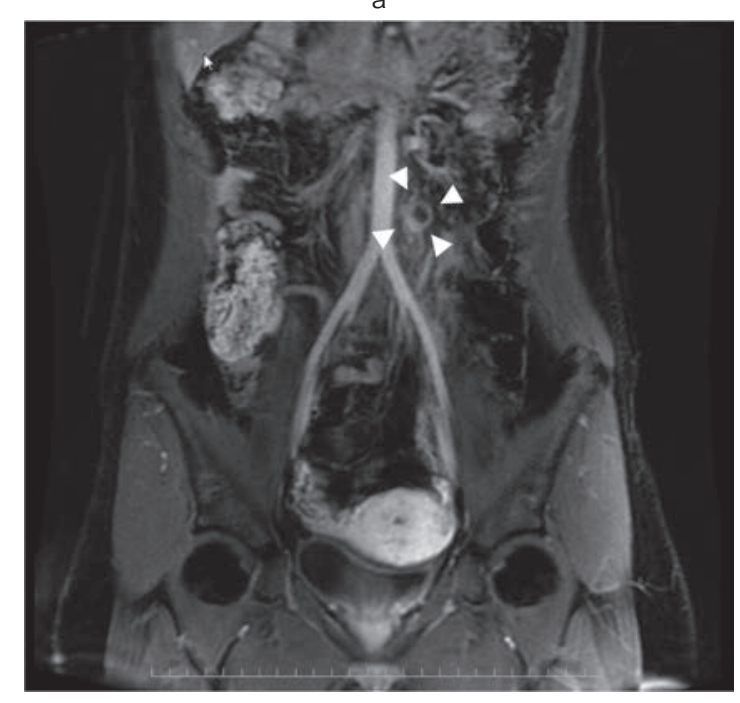

b
腹腔鏡所見、造影CT、造影MRI所見、および術 中超音波所見を加味することで、合併症を起こす ことなく絨毛組織を完全に摘出することができた。

異所性妊娠の頻度は全妊娠の $0.5 \sim 1 \%$ 、そ の局在部位は卵管 $97 \%$ 、卵管間質部や頸管妊娠 2 $\%$ 、卵巣 $0.5 \%$ 、腹腔内 $0.3 \%$ 、他 $0.2 \%$ と報告されて おり ${ }^{1)}$ 、後腹膜妊娠は非常に稀である。後腹膜腔 への妊娠組織の迷入についてはいくつかの仮説が ある。腹膜表面に着床した妊娠組織の絨毛が、腹 膜を浸潤して後腹膜腔に入るという説 ${ }^{4}$ や、子宮 内腔と後腹膜の欠損部に瘦孔が形成され直接後腹 膜腔に入るという説もある。卵管の子宮側切除断 端が後腹膜腔と連続しているという説もあり ${ }^{5)}$ 、 Yoder, Nらは腹腔内妊娠の症例報告をレビュー し、卵管妊娠の既往が37\%にあり、卵管手術の既 往が50\%にあったと報告している6)。Huang, Xら は後腹膜妊娠に限った27例の症例報告をレビュー し、卵管手術の既往が $41 \%$ と多かったことから、 卵管手術が後腹膜の欠損をきたし、その欠損部を 介して受精卵が後腹膜に着床するという仮説を述 べている7)。異所性妊娠のリスク因子は妊娠部位

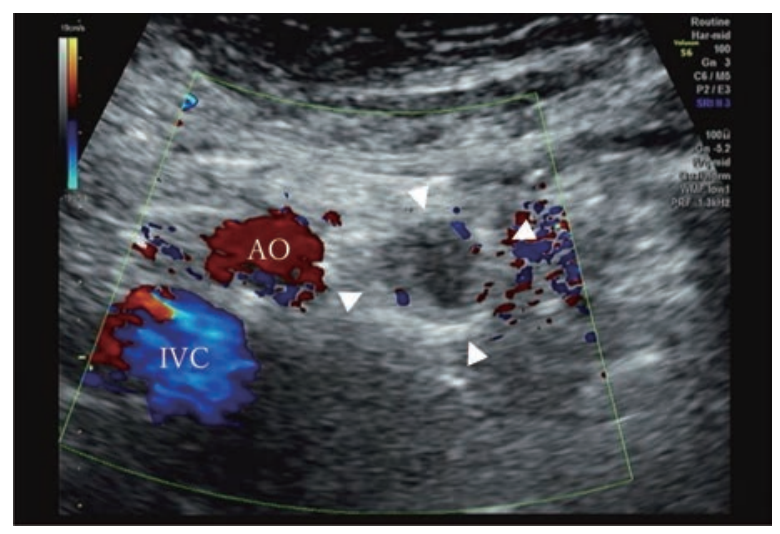

C

図2 画像診断

a. 造影CT画像 : 腹部大動脈左側に周囲がリング状に造影され る襄胞性腫瘤を認めた。

b. T2強調MRI画像冠状断 : 腹部大動脈bifurcationの頭側 $2 \mathrm{~cm}$ に同様の腫瘤を認めた。

C. 経腹超音波画像 : 胎囊様の腫瘤を確認できたが、卵黄囊お よび胎児心拍は不明瞭であった。

$\mathrm{AO}$; 腹部大動脈、IVC; 下大静脈 


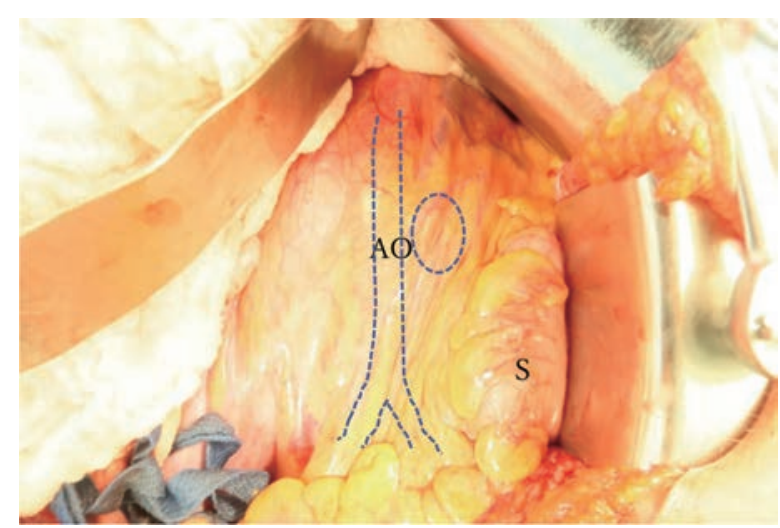

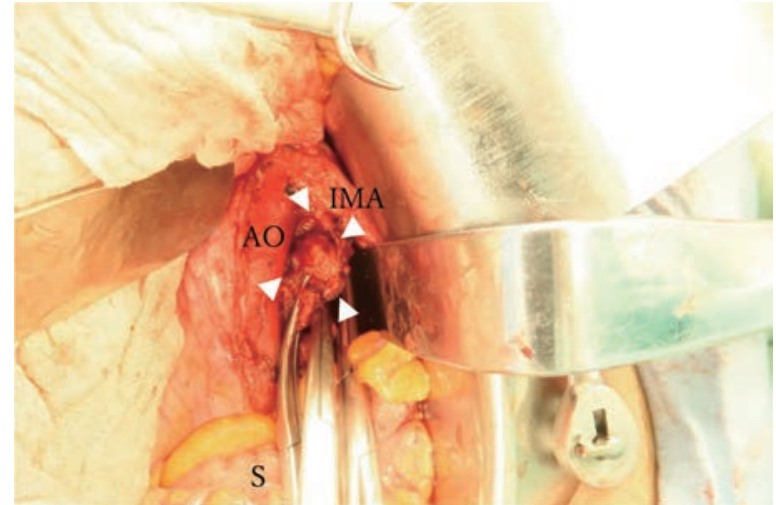

b

図3開腹術中所見

a. 腫瘤を覆う腹膜の表面は平滑であった。

b. 下腸間膜動脈、卵巣動静脈、尿管を左側に避け、腹部大動脈左側の腫瘤を挟鉗し摘出した。

$\mathrm{AO}$; 腹部大動脈、IMA; 下腸間膜動脈、S; S 状結腸

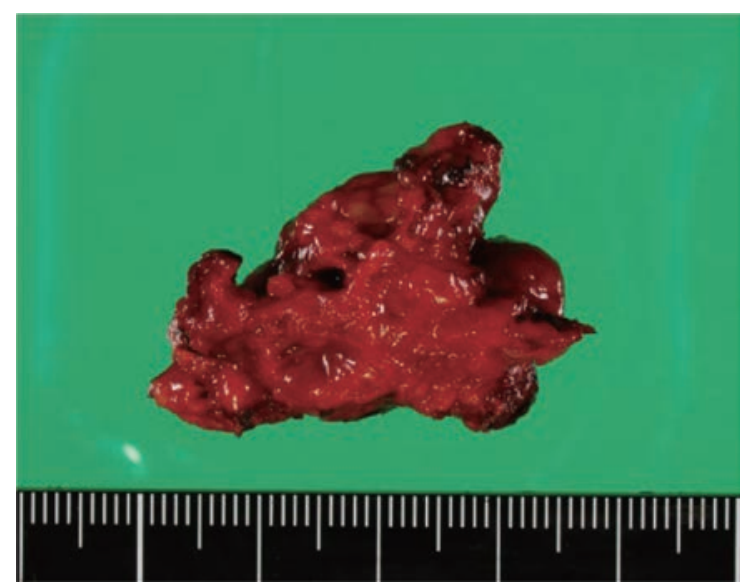

a

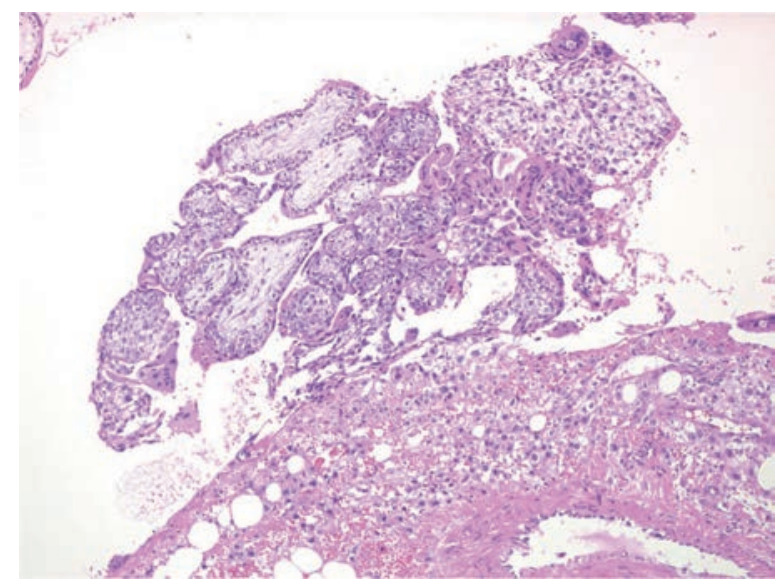

b

に関わらず、異所性妊娠の既往、中絶手術の既往、 卵管手術の既往、不妊症や生殖補助医療 (ART) の既往、骨盤内炎症性疾患 (PID)、喫煙などで ある ${ }^{8)}$ 。ART妊娠は自然妊娠に比較し異所性妊娠 が多く、ART症例の増加によって異所性妊娠も 増加している ${ }^{6)}$ 。IVF-ET後の異所性妊娠の罹患

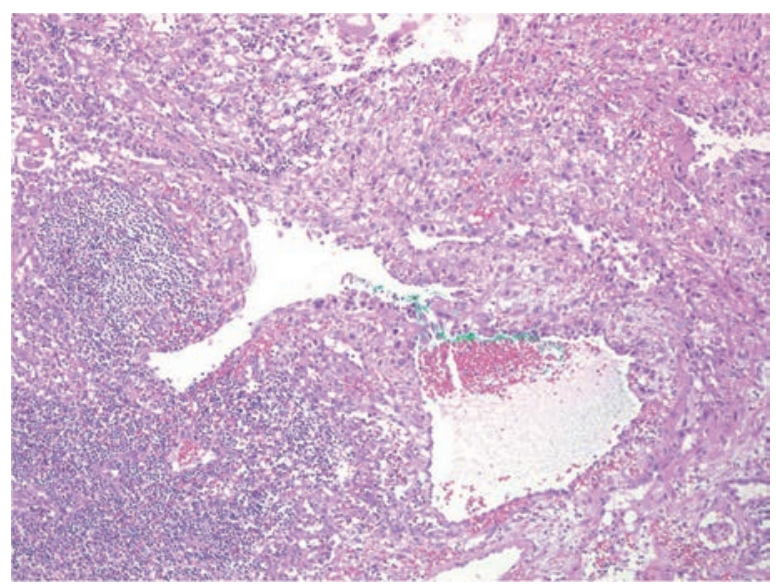

C

図4検体写真

a. 摘出標本 : 中央が䄉毛組織で、後腹膜脂肪組織と一塊とな っている。

b. HE染色（×100）：やや粗大な妊娠初期の緁毛を認め、後 腹膜の脂肪組織に中間型が主体のトロフォブラストの浸潤 を認める。

c. HE染色 $(\times 200)$ : 緁毛の近傍にリンパ節構造を認め、リ ンパ節内の血管をトロフォブラストが置換している。

率は2.2〜 $4.9 \%$ と報告され ${ }^{9)}$ 、後腹膜妊娠の報告も ある ${ }^{10-12)}$ 。ART後の後腹膜妊娠では、子宮内への 胚移植後に移植胚が逆行性に子宮外へ着床する か、医原性の子宮穿孔によって子宮外に肧移植を した可能性が推察されている ${ }^{10)}$ 。しかし不妊治療 歴がない症例や、卵管切除術などの手術既往がな 
い症例、初めての妊娠での症例でも後腹膜妊娠の 報告がある ${ }^{13-17)}$ 。大動脈周囲の後腹膜妊娠では摘 出した絨毛組織にリンパ組織が含まれていたこと から、子宮体癌がリンパ節行性転移をするように 肧がリンパ管を介して後腹膜に運ばれる可能性も 推察されている ${ }^{4)}$ 。後腹膜腔で妊娠が成立する共 通のメカニズムの解明は難しく、個々の症例毎に 異なっている可能性がある。

異所性妊娠の診断は、異所性に胎児心拍が確認 できれば確実である。そうでない場合でも病歴よ り異所性妊娠を疑うことは比較的容易であるが、 確定診断は䋐毛組織の確認と摘出後のhCGの陰性 化である。異所性妊娠を疑うものの局在が不確か な場合に審查腹腔鏡を行うことは診断的に意義が あると思われる。妊娠の局在部位を直接確認する ことができる検査の一部としても取り入れやす く、妊娠部位が確定されれば多くの場合はそのま ま妊娠組織の摘出まで可能である。後腹膜腔のよ うな腹腔外への妊娠においても、審査腹腔鏡は腹 腔内への妊娠を除外することができ、子宮内膜掻 爬術による流産などの子宮内異常妊娠の除外診断 と同様に術前診断に有用である。審査腹腔鏡で卵 管に異所性妊娠の所見が認められなかった場合に は大網や骨盤内から横隔膜下腹膜まで十分な観察 が重要である。後腹膜妊娠の症例報告でも後腹膜 妊娠の術前診断は難しく、施設に腹腔鏡設備がな いため試験開腹術を行った症例13,18)、審查腹腔鏡 で後腹膜血腫を確認し、そのまま開腹根治術へ移 行した症例 ${ }^{5)}$ や後日根治手術を行った症例 ${ }^{1920)}$ な どがあり、後腹膜妊娠の診断における審査腹腔鏡 の有用性が示されている。卵管妊娠や卵管間質部 妊娠の術前診断で腹腔鏡手術を行ったものの診断 がつかず審査腹腔鏡に終わった症例もあり ${ }^{21,22)}$ 、 画像評価で後腹膜妊娠と診断した上で根治開腹術 にも審査腹腔鏡を併用している症例もある ${ }^{1)}$ 。こ のように審査腹腔鏡は画像診断では明らかになら ないような腹腔内病変の評価に優れた検査の一つ として様々な利用をされているが、全身麻酔管理 のもと、ポート造設時には皮虐、筋膜、腹膜切開 が必要であり、腸管や血管損傷などの危険も伴う ので、周術期合併症への十分な注意が必要である。

審査腹腔鏡の陰性所見だけでは後腹膜妊娠の診 断には至らない。経腟超音波検査は子宮支持勒带 の間膜内や閉鎖腔など、骨盤内にとどまる後腹膜 妊娠の描出は可能である。しかし骨盤内の後腹膜 妊娠では卵管妊娠や卵管間質部妊娠と術前診断を されていることも多く、経胵超音波検查での後腹
膜妊娠の診断には限界がある。異所性妊娠が疑わ れるにも関わらず経腟超音波検査で診断がつかな い場合には、卵管妊娠以外の異所性妊娠を疑って 経腹超音波検査で検查範囲を広げるべきである。 超音波検查は妊婦に安全に行うことができ、かつ 典型的な胎囊、卵黄囊像の描出や胎児心拍動の確 認によって妊娠の診断に最も優れた検查法であ る。超音波検査で描出できない後腹膜妊娠の局在 診断にはCTやMRIが有用である。特に造影CT検 查では絨毛組織に造影剂の集積があり、リング状 に造影効果のある胎囊が確認できる。しかし画像 診断だけでは後腹膜血腫と診断されることもあ $3^{15)}$ 。後腹膜妊娠の確定診断は摘出物の病理所見 によってなされ、摘出後に血中hCG值が陰性化す ることを確認する必要がある。画像診断によって 絨毛付着部と周囲大血管との関係を詳細に解析し ておくことは、䄉毛組織の摘出の可否や手術によ る血管損傷の可能性などを評価する術前のリスク アセスメントとして重要である。一般的に妊娠中 の超音波検查以外の画像検查は胎児への放射線被 ばくの影響も懸念されるため、正常妊娠の可能性 がある限り、その使用は避けるべきである。異所 性妊娠を疑うものの経腟超音波検査で可視範囲内 に妊娠が確認できない場合には、まず経腹超音波 検査で腹部まで描出範囲を広げていくべきであ る。さらに妊娠週数、血中hCG值から正常妊娠の 可能性が極めて低ければ、CTやMRI検查なども 積極的に導入し、後腹膜妊娠の早期診断に努める べきである。異所性妊娠の頻度はARTにより増 加するが、ARTによる不妊治療中は自然妊娠よ り妊娠週数がより正確であるので、妊娠を希望し ている患者背景を十分に配慮しながらも早期診断 のために画像診断を適切に取り入れるべきであ る。後腹膜妊娠は腹腔内出血がないため自覚症状 がそしいことが多い。特異的な自覚症状や兆候が ないため、早期に診断をするのは難しく、しばし ば診断を誤ることもある。診断の遅れにより妊娠 組織が成長し、後腹膜の大血管へ近接、浸潤する ことで大血管損傷の危険もあり、手術での大血管 損傷の危険度も上がる。よって早期診断、治療が 重要である。

後腹膜妊娠であっても他の異所性妊娠と同様 に、基本的な治療は外科的な絨毛組織の摘出であ るが、局在部位も様々であることから、確立した 治療方針はなく、過去の報告においても様々な治 療がなされている。後腹膜腔は大動脈や大静脈や その分枝、腎臟、尿管など、豊富な血液供給を得 
ているいくつかの重要な臟器を含んでおり、後腹 膜妊娠は大量出血や重大な臟器障害を起こす可能 性がある。手術にあたっては後腹膜腔内の血管損 傷を避けるため、その解剖を熟知する必要があり、 症例報告でも産婦人科医だけでなく腹部外科や血 管外科などと合同手術を行っていた ${ }^{12,18)}$ 。根治手 術における腹腔鏡手術は後腹膜大血管への絨毛浸 潤により止血が難しくなる可能性もあるため、適 応に関しては慎重に判断すべきである。後腹膜妊 娠を画像診断や審查腹腔鏡で診断しても、根治手 術は開腹術を選択している報告が多いが、Siow, $\mathrm{A}$ らの報告以降腹腔鏡手術により完治し得た症例 報告も増えており ${ }^{23)}$ 、Persson, Jらはロボット支 援手術での根治手術を報告している ${ }^{21)}$ 。腹腔鏡下 の根治手術は主に円勒帯、基勒帯、仙骨子宮勒帯 といった子宮支持勒帯内、卵管間膜内、閉鎖腔と いった骨盤内の後腹膜妊娠で行われている が9,21-26)、Bae, S.U.ら、Meshulam, Mら、Lu, Qら は下大静脈に接する絨毛組織の摘出も報告してい $3^{27-29)}$ 。腹腔鏡手術では合併症や出血時の開腹手 術移行の準備は必須である。後腹膜妊娠において も血管浸潤像があり手術での摘出に困難が予測さ れる症例では術前メソトレキセート（MTX）療 法が試みられている ${ }^{12,13)}$ 。MTX療法でも流産時に 出血をきたすこともあるので、後腹膜妊娠でも背 部痛、ショック症状といった出血の兆候には注意 が必要である。止血操作に手術対応が必要となる こともあるので、手術に対応できる体制は必要で ある。また術後に遺残絨毛に対してMTXを使用 した報告や ${ }^{25)}$ 、CTガイド下のMTXの局所注射に より手術を回避できた報告もある7)。本邦では異 所性妊娠へのMTX投与は適応外使用であるので、 使用は慎重にすべきである。

今回の症例は我々にとって初めての後腹膜妊娠 であった。左側卵管妊娠での摘出手術既往があり、 経腟超音波検査で右卵管が腫大していたことから 右卵管妊娠を疑い、他に大網などの腹腔内妊娠ま でを想定して審查腹腔鏡を行った。異所性hCG産 生腫瘍なども念頭に胸腹部CT検査を行い、傍大 動脈左側に胎囊様の腫瘤を発見した。経腹超音波 検査で胎囊様の囊胞は確認できたが、明らかな卵 黄囊や胎児心拍は確認できず診断に難渋した。文 献で傍動脈リンパ節領域への妊娠の報告例を確認 し、後腹膜妊娠を一番に疑った。後腹膜妊娠の診 断確定は絨毛組織の確認であり、画像検査でも胎 囊と下大動脈の間に間隙を確認し、血管損傷なく 摘出可能と判断できたため、可及的に絨毛組織を
摘出し診断を確定するために再手術を行うことと した。術野で超音波検查も併用しながら局在や血 管の位置関係を確認し、低位傍大動脈リンパ節の 郭清術を行う要領で下腸間膜動脈や左卵巣動静 脈、尿管の走行に留意しながら緁毛組織を完全に 摘出した。迅速病理検査で絨毛組織が含まれるこ とを確認し、最終病理診断で後腹膜妊娠と診断し た。左卵巣に黄体囊胞があったことより、左卵巣 から排卵した卵は腹腔内で妊娠し、腹膜を浸潤し て後腹膜腔へ着床した可能性、既往手術の左卵管 間膜の腹膜欠損部から骨盤漏斗勒帯に沿って迷入 し着床した可能性が考えられた。病理診断では絨 毛着床部付近にリンパ節構造も確認できたことか らリンパ行性迷入の可能性なども推察された。

審查腹腔鏡は後腹膜妊娠の診断においても、卵 管妊娠や腹腔妊娠を除外することにより、画像診 断と共に診断に有用な手段であった。後腹膜妊娠 は経験したことがない産婦人科医がほとんどであ る。後腹膜妊娠は稀な妊娠で、病態は様々である が、異所性妊娠の一つとしての認識は必要であろ う。近年では婦人科悪性腫瘍手術で後腹膜リンパ 節郭清術を鏡視下手術で行える施設も増えてきて いることから、今回のような後腹膜妊娠であれば 鏡視下手術で診断から治療まで完遂しうる施設も 増えてくると思われる。

\section{【結語】}

審查腹腔鏡は異所性妊娠の診断のうち、後腹膜 妊娠の診断においても有用である。異所性妊娠を 疑うもののその局在部位が不明な場合には、広範 囲な画像診断と合わせて、審査腹腔鏡は早期診断 の一助となり、早期治療へと慗がる。画像診断で は絨毛組織の後腹膜血管への侵襲の評価も重要で ある。後腹膜妊娠の特殊性、希少性より治療方針 は様々である。根治手術への腹腔鏡手術の適応に 関しては、後腹膜血管の損傷の危険もあるため慎 重に判断すべきである。本論文の要旨は第58回日 本産科婦人科内視鏡学会において発表した。すべ ての著者は開示すべき利益相反はない。

\section{【文 献】}

1) Veleminsky, M., et al.: A rare case of ectopic pregnancy - retroperitoneal ectopic pregnancy. Neuro Endocrinol Lett 2018; 39(3): 156-159.

2 ) Richardson, A., et al.: Accuracy of first-trimester ultrasound in diagnosis of tubal ectopic pregnancy 
in the absence of an obvious extrauterine embryo: systematic review and meta-analysis. Ultrasound Obstet Gynecol 2016; 47(1): 28-37.

3 ) Creanga, A.A., et al.: Pregnancy-Related Mortality in the United States, 2011-2013. Obstet Gynecol 2017; 130(2): 366-373.

4 ) Hall, J.S., et al.: Retroperitoneal ectopic pregnancy. J Obstet Gynaecol Br Commonw 1973; 80(1): 92-4.

5 ) Reid, F. and M. Steel.: An exceptionally rare ectopic pregnancy. BJOG 2003; 110(2): 222-3.

6 ) Yoder, N., R. Tal, and J.R. Martin: Abdominal ectopic pregnancy after in vitro fertilization and single embryo transfer: a case report and systematic review. Reprod Biol Endocrinol 2016; 14(1): 69.

7 ) Huang, X., et al.: Conservative Management of Retroperitoneal Ectopic Pregnancy by Computed Tomographic-guided Methotrexate Injection in the Gestational Sac: 2 Case Reports and Literature Review. J Minim Invasive Gynecol 2019; 26(6): 11871192.

$8)$ Parker, V.L. and M. Srinivas: Non-tubal ectopic pregnancy. Arch Gynecol Obstet 2016; 294(1): 19-27.

9 ) Shinsuke K., et al.: A case of abdominal pregnancy following in vitro fertilization and embryo transfer treated with laparoscopic surgery. Gynecology and Minimally Invasive Therapy 2015; 5(3): 132-133.

10) Ferland, R.J., et al.: An ectopic pregnancy in the upper retroperitoneum following in vitro fertilization and embryo transfer. Obstet Gynecol 1991; 78(3 Pt 2): 544-6.

11) Dmowski, W.P., et al.: Retroperitoneal subpancreatic ectopic pregnancy following in vitro fertilization in a patient with previous bilateral salpingectomy: how did it get there? J Assist Reprod Genet 2002; 19(2): 90-3.

12) Iwama, H., et al.: A case of retroperitoneal ectopic pregnancy following IVF-ET in a patient with previous bilateral salpingectomy. Am J Perinatol 2008; 25(1): 33-6.

13) Okorie, C.O.: Retroperitoneal ectopic pregnancy: is there any place for non-surgical treatment with methotrexate? J Obstet Gynaecol Res 2010; 36(5): 1133-6.

14) Pak, J.O., et al.: Retroperitoneal Ectopic Pregnancy. Obstet Gynecol 2018; 132(6): 1491-1493.

15) Yang, Y., et al.: Diagnosis and surgical therapy of the retroperitoneal ectopic pregnancy: A case report. Int J Surg Case Rep 2018; 49: 21-24.

16) Zhang, M. and L.L. Qin: A case of retroperitoneal para-aortic ectopic pregnancy detected by sonography. J Clin Ultrasound 2018; 46(6): 412-414.

17) Lee, J.W., K.M. Sohn, and H.S. Jung: Retroperitoneal ectopic pregnancy. AJR Am J Roentgenol 2005;
184(5): 1600-1.

18) Ouassour, S., et al.: Retroperitoneal Ectopic Pregnancy: Diagnosis and Therapeutic Challenges. Case Rep Surg 2017; 2017: 9871865.

19) Lin, J.X., et al.: Primary obturator foramen pregnancy: a case report and review of literature. Chin Med J (Engl) 2008; 121(14): 1328-30.

20) Yoon, S.H., et al.: A case of retroperitoneal ectopic pregnancy. Korean J Obstet Gynecol 2012; 55(1): 5963.

21) Persson, J., et al.: Histopathology indicates lymphatic spread of a pelvic retroperitoneal ectopic pregnancy removed by robot-assisted laparoscopy with temporary occlusion of the blood supply. Acta Obstet Gynecol Scand 2010; 89(6): 835-9.

22) Protopapas, A., et al.: Ultrasound-assisted intraoperative localization and laparoscopic management of a previously missed unruptured retroperitoneal ectopic pregnancy. Gynecological Surgery 2014; 11(3): 207-211.

23) Siow, A., B. Chern, and Y. Soong: Successful laparoscopic treatment of an abdominal pregnancy in the broad ligament. Singapore Med J 2004; 45(2): 88-9.

24) Apantaku, O., P. Rana, and T. Inglis: Broad ligament ectopic pregnancy following in-vitro fertilisation in a patient with previous bilateral salpingectomy. Journal of Obstetrics and Gynaecology 2006; 26(5): 474-474.

25) Martinez-Varea, A., et al.: Retroperitoneal ectopic pregnancy after intrauterine insemination. Fertil Steril 2011; 95(7): 2433 e1-3.

26) You, J.Y., et al.: A case of retroperitoneal ectopic pregnancy of obturator fossa. Korean J Obstet Gynecol 2011; 54(12): 830-835.

27) Bae, S.U., et al.: Laparoscopic treatment of early retroperitoneal abdominal pregnancy implanted on inferior vena cava. Surg Laparosc Endosc Percutan Tech 2009; 19(4): e156-8

28) Meshulam.M, et al.: Retroperitoneal Pre-Caval Abdominal Pregnancy. Journal of Minimally Invasive Gynecology 2018; 25(7): S151-S152.

29) Lu, Q., Z. Zhang, and Z. Zhang: Laparoscopic Management of Retroperitoneal Ectopic Pregnancy. J Minim Invasive Gynecol 2019; 26(3): 405-406.

投稿日：2020年 6 月 1 日 採択日：2020年 8 月 12 日 